\title{
Management of Cognitive Information and its Relation to the Cognitive Interaction of University Students
}

\author{
AL-Dulaimi Hassan Khlebus \\ University of Bucharest, Faculty of Psychology and Educational Sciences, \\ Bucharest, Romania \\ Ministry of Education, Iraq \\ AL-Chaabawi Kadhim Mohsin \\ Ministry of Higher Education, Iraq \\ Khachi Ahmed Dhahir \\ Ministry of Education, Iraq
}

doi: 10.19044/ejes.v4no4a4 URL:http://dx.doi.org/10.19044/ejes.v4no4a4

\begin{abstract}
After reviewing the studies and literature that dealt with information management, it was apparent that many students failed to manage and process information during their learning process. This is not due to a decline in the degree of intelligence or lack of tendency to study, but due to the lack of learning processes that include planning, monitoring, evaluation and control of their cognitive abilities. Therefore, the current research will try to identify the level of information management knowledge of university students and what is the relationship between the management of knowledge information and knowledge overlap?
\end{abstract}

Keywords: Cognitive information, cognitive interaction, attention.

\section{Introduction}

Knowledge management is an important process in student activity, so efforts must be made to try to organize self-learning so that they can continue to deal with their educational duties and meet challenges. Cognitive management is an important basis for reaching the goals that are planned and planned with awareness and accuracy. Knowledge management plays an important role in our lives and the life of the student in particular. The importance of the current research stems from the importance of the university students and their active role in the development of education. 
The current research aims to identify:

1. Management of knowledge of university students.

2. Differences in knowledge management according to gender variables (males, females) and (scientific, literary).

3. Knowledge Interference among university students.

4. Differences in knowledge management according to gender variables (males, females) and (scientific, literary).

Limitations of research: The current research is determined by the Mustansiriya University students of males and females and scientific and humanities for the academic year (2016-2017).

\section{Terminology}

Information Management has been defined as the ability to use skills and strategies in a specific direction for the most efficient processing of information, including management, preference and summary (Schraw\&Denniso, 1994). Adkin (1997) has described it as the ability of learners to control knowledge processes during the error, and to respond to avoid them to reach the correct results. According to Bandura (2005) it is a moral act that involves the work of things that come with knowledge satisfaction and a sense of self-worth.

Knowledge Interference has also been defined in various ways, for example as cognitive process that leads to reduced cognitive competence and academic performance (Sarsan,1988), as a state of distraction when performing certain tasks (Harnishfeger \& Bjorklund, 1996), and as cutting the way for any knowledge processing and memory buffering (Northan, 2010).

\section{Theoretical framework}

This chapter includes a presentation of the most important theories that explain the variable of knowledge management and theories that explained the variable of cognitive overlap.

\subsection{Information Management:}

The theories in cognitive management are necessary to understand the conditions behind the motivation of the academic students, because the imbalance between inputs and outputs leads to a state of negativity. Pandora's cognitive social learning theory (1977-1986) states that cognitive management processes include cognitive observation as a performance monitor even if attention is not complete.

According to Brown's Theory (1987), there is a distinction between learning and managing knowledge. Learning knowledge cannot be stable, but stability may be late or weak. The first step depends more on the environment than on age. The theory of Maykenbaum and Esseno (1979) holds that the 
management of cognitive information is carried out by cognitive instruction and cognitive discourse (Abu Riash, 2006, 354). Zimmerman's Information Management Theory of Information is based on Pandora's three-dimensional paradigm of reciprocal determinism, which assumes that cognitive, environmental, and behavioral factors operate separately and are internally dependent on learner interaction with academic tasks.Piaget's Theory of Cognitive Information Management believes that the child's activity is a collection of activities that attempt to understand the stimuli or solve the problem. These activities lead to new cognitive structures. Two processes that occur during cognitive management are representation and harmonization.

Knowledge Interference (Sarason, 1990) provided an important interpretation of the concept of cognitive overlap in two main areas:

1. Job-related ideas: a set of negative thoughts about the self and related to the individual's performance of the tasks assigned to him that relate to the level of his abilities and abilities.

2. Ideas that are not related to the tasks: the ideas that feel the individual tension and away from the task assigned to him, such as thinking of his family and games and his friends and negative thoughts about himself and others.

\subsection{Cognitive overlap:}

The researchers who studied the cognitive overlap faced the challenges of distinguishing between internal and external ideas. The interior reflects ideas related to completion of tasks (external to duty) and external ones that refer to extraneous (non-relevant) ideas that keep the individual from completing the task assigned to it (Broadbent.etal, 1982: 16).Triesman notes that the cognitive system allows all stimuli to enter and manipulates relevant stimuli and weakens others. Deutch and Deutsches, however, pick the information too late, allowing the cognitive device to pass all possible stimuli and only select the relevant information in the latter.

Johnson, Johnston and Wilson (1980) believe that the cognitive system selects stimuli according to individuals' goals and the difficulties associated with the task. The higher the number of stages of cognitive processing, the higher the cognitive resources required. The lowest number of information to the cognitive device. Nayser suggests that the required expertise should be sought in the environmental conditions in which it occurred, or in circumstances similar to those where experience was acquired (Matias, 2005:67).

One of the most important factors that control cognitive overlap is the distribution of attention sources. The experience of John Ridley Stroop (1935) suggests that the distribution of attention sources is done by selecting the stimulus we want to focus on, knowing how to make this choice (how to adjust the distribution of sources of our attention), not being preoccupied with 
unimportant stimuli. The area of the central apparatus, which plays the role of information processing, is limited to the retention of sources of attention and learners, in turn, from which to derive the two important tasks (Kahneman, 1973). Loss of control over thoughts because of anxiety or ambition to participate in tasks and good focus on them, play an important role in behavior (Kazdin, 1990: 73_79).) Perceptions of the threat aspects and the negative personal effects of failure make the individual less capable of addressing internal and environmental information related to duty (Trapp \& Kausler, 1958: 3134) and their attention is weak.

\section{Research methodology and procedures}

This chapter includes procedures and methodology of research.The descriptive descriptive approach was used to study the correlation between variables. The research community consists of students of the Mustansiriya University College for the academic year 2016-2017 in 13 of them (8) humanities and (5) scientific, and the total number of students (22820) with (12361) students and (10459) by gender, as in table (1).

Table (1). The research community (Mustansiriya University students) divided by gender and specialization.

\begin{tabular}{|c|c|c|c|c|c|}
\hline \multirow{2}{*}{ Sequence } & \multirow{2}{*}{ College Name } & \multirow{2}{*}{ Specialization } & \multicolumn{2}{|c|}{$\begin{array}{l}\text { Number } \\
\text { students }\end{array}$} & \multirow{2}{*}{ Total } \\
\hline & & & Male & Females & \\
\hline 1 & Medicine & \multirow{5}{*}{ 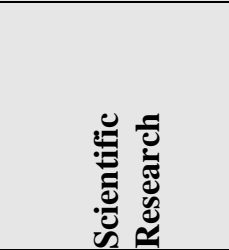 } & 477 & 868 & 1345 \\
\hline 2 & Dentist & & 130 & 221 & 351 \\
\hline 3 & the pharmacy & & 134 & 314 & 448 \\
\hline 4 & Engineering & & 606 & 850 & 1456 \\
\hline 5 & Science & & 1375 & 774 & 2149 \\
\hline 6 & Basic Education & \multirow{8}{*}{ 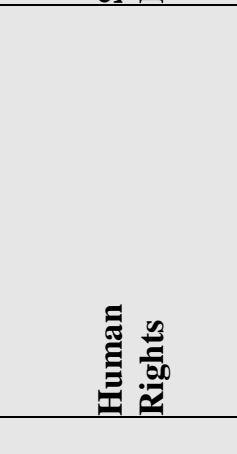 } & 1478 & 2093 & 3571 \\
\hline 7 & Arts & & 2931 & 1547 & 4478 \\
\hline 8 & education & & 2138 & 1989 & 4127 \\
\hline 9 & $\begin{array}{l}\text { Administration } \\
\text { and Economics }\end{array}$ & & 2007 & 1062 & 3069 \\
\hline 10 & Law & & 538 & 482 & 1020 \\
\hline 11 & Political Science & & 327 & 240 & 567 \\
\hline 12 & $\begin{array}{l}\text { physical } \\
\text { education }\end{array}$ & & 220 & 19 & 239 \\
\hline \multicolumn{2}{|l|}{ Grand total } & & 12361 & 10459 & 22820 \\
\hline
\end{tabular}

The current research sample consists of (400) students. The sample was randomized according to the random cluster method. The 400 students were divided according to gender (200) students and (200) students, divided according to the humanitarian specialization with (200) students and scientific 
specialization by 200 students. Namely education, literature, engineering and science, and Table (2) illustrates this.

Table (2). Sample of the research distributed by college, gender and specialization

\begin{tabular}{|l|l|l|l|l|}
\hline the college & Specialization & Sex & Total \\
\cline { 3 - 4 } & & Males & Females & \\
\hline Education & $\begin{array}{l}\text { Humanitarian } \\
\text { assistance }\end{array}$ & 50 & 50 & 100 \\
\hline Arts & $\begin{array}{l}\text { Humanitarian } \\
\text { assistance }\end{array}$ & 50 & 50 & 100 \\
\hline Engineering & $\begin{array}{l}\text { Scientific } \\
\text { research }\end{array}$ & 50 & 50 & 100 \\
\hline Science & $\begin{array}{l}\text { Scientific } \\
\text { research }\end{array}$ & 50 & 50 & 100 \\
\hline Total & & $\mathbf{2 0 0}$ & $\mathbf{2 0 0}$ & 400 \\
\hline
\end{tabular}

The research tool is a standardized method of measuring a sample of behavior, and the selection of the tool is important to identify the property to be measured (Anastasi, 1976: 15).

In the research, two measures were used: the measure of the management of cognitive information and cognitive overlap.

\subsection{The measure of management of cognitive information:}

Adoption of the measure of management of cognitive information for (Musawi 2011) in the final form, which consists of (33) paragraph, adopting the method (Likart Likert) in the measurement, the status of the fifth runway of alternatives to answer the scale (apply to me exactly, The researchers used the method of retesting and the coefficient of stability (0.81), the equation of Alpha Cronbach and the coefficient of stability (0.74), the road (0.75).

\subsection{The discriminatory power of paragraphs:}

The purpose of the discriminatory power of paragraphs is their ability to distinguish between the highest and lowest levels of individuals in relation to the attributed measured by the paragraph (Shaw, 1967, p. 45). Through the following two methods:

A. Method of management of cognitive information was applied to a sample of 400 students from Mustansiriya University in scientific and human subjects. After correcting the scores of each individual on the scale and finding the total score. Using the method of the two terminal groups, $27 \%$ of the students 'grades were obtained, representing the top group and $27 \%$ of the students' grades. The group represents 108 students. Significance Between the mean of the upper and lower groups. The calculated $\mathrm{T}$ value was an indicator for distinguishing each paragraph by comparing it with the table value (1.96) 
with a level of 0.05 and with a freedom degree. 214 The test results showed that all the paragraphs of the scale are as distinct in Table (3).

Table (3). Parameters of the measures of the management of cognitive information in the form of two terminal samples

\begin{tabular}{|c|c|c|c|c|c|}
\hline \multirow{2}{*}{ 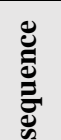 } & \multicolumn{2}{|l|}{ High Group } & \multicolumn{2}{|c|}{ The lower group } & \multirow{2}{*}{$\begin{array}{l}\text { Calculated } T \\
\text { value }\end{array}$} \\
\hline & $\begin{array}{l}\text { Arithmetic } \\
\text { mean }\end{array}$ & $\begin{array}{l}\text { standard } \\
\text { deviation }\end{array}$ & $\begin{array}{l}\text { Arithmetic } \\
\text { mean }\end{array}$ & $\begin{array}{l}\text { standard } \\
\text { deviation }\end{array}$ & \\
\hline 1 & 4,54 & 0,719 & 3,56 & 1,208 & 5,130 \\
\hline 2 & 4,89 & $\mathbf{0 , 3 1 7}$ & 3,54 & 1,128 & 8,479 \\
\hline 3 & 4,80 & $\mathbf{0 , 5 2 8}$ & 3,37 & 1,087 & 8,674 \\
\hline 4 & 4,61 & 0,685 & 3,07 & 1,061 & 8,943 \\
\hline 5 & 4,33 & 0,911 & 3,22 & 1,254 & 5,268 \\
\hline 6 & 4,63 & 0,917 & 3,31 & 1,130 & 6,639 \\
\hline 7 & 3,59 & 1,367 & 2,78 & 1,355 & 3,111 \\
\hline 8 & 4,41 & $\mathbf{0 , 8 1 3}$ & 3,41 & 1,125 & 5,295 \\
\hline 9 & 4,20 & 1,053 & 2,57 & 1,253 & 7,317 \\
\hline 10 & 4,56 & 0,744 & 3,17 & 1,129 & 7,551 \\
\hline 11 & 4,61 & 0,656 & 3,09 & 1,086 & 8,792 \\
\hline 12 & 3,98 & 1,310 & 2,74 & 1,277 & 4,984 \\
\hline 13 & 4,85 & 0,408 & 3,39 & 1,220 & 8,360 \\
\hline 14 & 4,76 & 0,671 & $\mathbf{3 , 0 7}$ & 1,344 & 8,244 \\
\hline 15 & 4,44 & 1,003 & 3,28 & 1,295 & 5,235 \\
\hline 16 & 4,85 & 0,492 & 3,30 & 1,093 & 9,541 \\
\hline 17 & 4,80 & 0,528 & 3,17 & 1,161 & 9,387 \\
\hline 18 & 4,52 & 0,947 & 3,20 & 1,279 & 6,071 \\
\hline 19 & 4,76 & $\mathbf{0 , 5 8 1}$ & 3,24 & 1,243 & 8,134 \\
\hline 20 & 4,78 & 0,572 & 2,91 & 1,033 & 11,642 \\
\hline 21 & 4,72 & 0,564 & 3,17 & 1,129 & 9,062 \\
\hline 22 & 4,76 & 0,581 & 2,76 & 1,181 & 11,171 \\
\hline 23 & 4,63 & $\mathbf{0 , 5 6 0}$ & 3,06 & 1,123 & 9,220 \\
\hline 24 & 4,67 & 0,644 & 3,13 & 1,304 & 7,767 \\
\hline 25 & 4,65 & 0,781 & 3,19 & 1,245 & 7,315 \\
\hline 26 & 3,11 & 1,538 & 2,09 & 1,404 & 3,594 \\
\hline 27 & 4,24 & 0,950 & 3,09 & 1,321 & 5,184 \\
\hline 28 & 4,56 & 0,664 & 2,80 & 1,105 & 10,028 \\
\hline 29 & 4,02 & 1,310 & 2,89 & 1,239 & 4,604 \\
\hline 30 & 4,80 & 0,528 & 3,15 & 1,235 & 9,019 \\
\hline 31 & 4,54 & 0,794 & 3,17 & 1,240 & 6,839 \\
\hline 32 & 3,91 & 1,233 & 2,89 & 1,239 & 4,283 \\
\hline 33 & 4,82 & $\mathbf{0 , 7 3 4}$ & 3,70 & 1,159 & 8,496 \\
\hline
\end{tabular}

The table $\mathrm{T}$ value is (1.96) at (0.05) and the freedom level (214)

B. This method is the best method used to calculate the internal consistency of the standard clauses (Esawi, 1985: 95). The use of the degree 
of relation of the paragraph to the total student score on the scale shows the strength of the paragraph's relation to the scale, On the assumption that the paragraph measures the part measured by the whole scale, and that the measure by which the paragraphs are selected accordingly is sincere in its construction.

The researchers used the Pearson correlation coefficient to extract the coefficient of correlation between the scores of each paragraph and the total degree of the individual on the scale. Statistical function (0.098) at a significance level (0.05) and a degree of freedom (398).

\subsection{Cykometric properties of the scale:}

The scale should have some basic cykometric characteristics, the most important of which is its sincerity and the stability of its degrees (Alam, 2000: 184), Because the measurement process requires the availability of many conditions in the construction of the tool for this confirms the measurement scientists need to verify the validity of the scale and stability, and researchers have verified the validity of the scale and stability through:

- Honesty virtual: The researchers presented the scale to a group of experts and arbitrators in the field of education and psychology has been adopted value of the percentage criterion for the opinion of the arbitrators on the validity of the scale or not, and the ratio was the acceptance rate of all paragraphs $100 \%$.

- Validation of construction: The validity of the construction of the scale depends on the method of the relationship of the degree of the paragraph to the overall degree of the scale, and the correlation of the degree of each paragraph in the field to which it belongs, which represents one of the indicators of the validity of the building and represent the structural honesty by the following methods discrimination paragraphs (Anastasi,1979).

\subsection{Stability of the scale:}

The researchers relied on the method of testing and retest in the extraction of stability. A sample of (100) male and female students from Al Mustansiriya University (Faculty of Education Education) and (Science) was selected. The test was repeated after two weeks of the first application. The stability of the scale was calculated using Pearson correlation coefficient. Stability (0.81). This value is an acceptable indicator of the stability of respondents' responses to the KMI and statistical significance at (0.05).

\subsection{The cognitive interference scale:}

The adoption of the cognitive interference scale of (Shammari 2015), consists of (36) paragraph and includes two areas, the field of ideas related to tasks (18) paragraphs, and the field of ideas unrelated to the tasks (18) The 
lowest grade to the highest grade (36-180), and the average mean of the scale (108).

\subsection{Statistical Analysis of the Cognitive Interference Scale:}

The discriminatory power of the paragraphs: For the purpose of extracting the discriminatory power of the paragraphs and excluding the nondistinguishing paragraphs, the overall scores obtained by the respondents were ranked from the highest degree to the lowest, and $27 \%$ of the answers representing the highest grades and $27 \%$ (27\%) of the sample size of (400) students. The researcher used the T-test for two independent samples to determine the statistical significance between the upper and lower groups of the two groups. The calculated T value is an indicator of GDP (1.96) at the level of significance (0.05) and the degree of freedom (214). The result of the analysis showed that all the paragraphs of the scale are distinct.

Validation of the scale: The validity of the scale has been verified by the correlation coefficient of the degree of the paragraph in the overall degree of the measure: Pearson correlation coefficient was used to extract the coefficient of correlation between the degree of each paragraph and the total score of the sample. All correlation coefficients were found to be statistically significant when compared with the table value (0.098) at the level of significance (0.05). This is a good indication of the veracity of the paragraphs and that the measure is honest to measure the phenomenon.

\subsection{The cykometric characteristics of the cognitive interference scale:}

1. Authentic honesty: The apparent honesty of the scale was achieved by presenting it to a group of arbitrators and experts in the field of psychology to judge the veracity of the paragraphs. The researchers adopted a percentage criterion for the experts' opinions on the validity of the scale or not and the acceptance rate for all paragraphs $(100 \%)$.

2. The validity of the building: The validity of the building was verified in a way that relates the degree of the paragraph to the overall degree of the scale, and the method of linking the degree of the paragraph to the degree of the field (Rabeea, 1994).

As for the stability indicators, the stability of the cognitive interference scale was verified by:

- $\quad$ Testing and re-testing: The stability of the scale was verified by applying it to a sample of (100) students, in a time interval (two weeks) between the two applications, and then using Pearson correlation coefficient between the two application grades High.

- $\quad$ Statistical means: For the purpose of achieving the objectives of the research, the use of the appropriate statistical means in this research using the statistical bag for social sciences (SPSS). 


\section{Results and discussions:}

This chapter will include a presentation and explanation of the results according to the research objectives, and the most important recommendations and proposals.

Objective 1: For the purpose of knowing the significance of the difference in the management of cognitive information among university students, the T-test was used for one sample as shown in Table (4).

Table (4). $T$ - Value, mean mean and arithmetic average of the variable cognitive information management.

\begin{tabular}{|l|l|l|l|l|l|l|}
\hline $\begin{array}{l}\text { the } \\
\text { sample }\end{array}$ & SMA & $\begin{array}{l}\text { Medium- } \\
\text { premise }\end{array}$ & $\begin{array}{l}\text { standard } \\
\text { deviation }\end{array}$ & $\begin{array}{l}\text { calculated } \\
\text { value }\end{array}$ & $\begin{array}{l}\text { Table } \\
\text { Value }\end{array}$ & $\begin{array}{l}\text { Level of } \\
\text { significance }\end{array}$ \\
\hline 400 & 124,57 & 99 & 16,54 & 31,30 & 1,96 & 0,05 \\
\hline
\end{tabular}

The results show that there is a statistically significant difference in favor of the research sample, which means that the research sample has a knowledge management of the information they receive in their studies. The researchers attribute this result to the good academic preparation and their experience and ability to manage many psychological, social and cognitive problems. Sound, and control behavior in many positions and their ability to take responsibility for future goals. This finding is consistent with the concepts of Pandora's cognitive theory, in which he emphasized that individuals have the ability to manage their behavior by observing, responding to, and responding to their behavior (Bandura, 1991: 288).

The second objective: In order to identify the differences of statistical significance in the cognitive information tool for variables (sex and specialization), the analysis of the binary variance was used as shown in Table (5).

Table (5). Mean and standard deviation of sample members by sex and specialization for knowledge management.

\begin{tabular}{|l|l|l|l|l|}
\hline Sex & Jurisdiction & Average & $\begin{array}{l}\text { standard } \\
\text { deviation }\end{array}$ & $\begin{array}{l}\text { Number of } \\
\text { sample } \\
\text { members }\end{array}$ \\
\hline \multirow{4}{*}{ Males } & Scientific & 106.00 & 12.75 & 62 \\
\cline { 2 - 5 } & Humanitarian & 103.79 & 19.25 & 107 \\
\cline { 2 - 5 } & Total & 104.60 & 17.15 & 169 \\
\hline \multirow{5}{*}{ Females } & Scientific & 106.01 & 15.29 & 94 \\
\cline { 2 - 5 } & Humanitarian & 112.09 & 15.77 & 137 \\
\cline { 2 - 5 } & Total & 109.62 & 15.83 & 231 \\
\hline \multirow{5}{*}{ Specialization } & Scientific & 106.00 & 14.29 & 156 \\
\cline { 2 - 5 } & Humanitarian & 108.45 & 17.83 & 244 \\
\cline { 2 - 5 } & Total & 107.50 & 16.57 & 400 \\
\hline
\end{tabular}


A - Sex variable (males, females): The result shows that the average female is higher than the average male.

B - Variable competence (scientific, human): The result shows that the average human competence is higher than the average scientific competence, and the summary of analysis of the binary variance is shown in Table (6).

Table (6) Summary of analysis of binary variance according to sex and specialization variables.

\begin{tabular}{|l|l|l|l|l|l|}
\hline $\begin{array}{l}\text { Source of } \\
\text { Contrast }\end{array}$ & $\begin{array}{l}\text { Total } \\
\text { squares }\end{array}$ & $\begin{array}{l}\text { Degree } \\
\text { of } \\
\text { freedom }\end{array}$ & $\begin{array}{l}\text { Average } \\
\text { squares }\end{array}$ & $\begin{array}{l}\text { Nutritional } \\
\text { value }\end{array}$ & Significance \\
\hline Sex & 2558.302 & 1 & 2558.302 & 9.542 & 0.002 \\
\hline specialization & 670.107 & 1 & 670.107 & 2.499 & 0.115 \\
\hline $\begin{array}{l}\text { Between } \\
\text { groups }\end{array}$ & 106442.437 & 397 & 268.117 & & \\
\hline Total & 109670.846 & 399 & & & \\
\hline
\end{tabular}

The results showed that there were differences between males and females and that females outperformed males in knowledge management. This difference can be attributed to the nature and characteristics of the female sex because of the excellence in controlling the management and organization of information, and therefore the girls resort to the use of strategies and methods that help them to memorize and remember all details of the situation or event. The results showed no statistically significant differences between scientific specialization and human competence in the level of knowledge management. This result can be explained by Bandroa's assertion of the role of an expert in the management and organization of cognitive information and because the scientific and human subjects are in the same school stage, ie they have the same level of information management and organization as they have the same abilities and skills.

The third objective was to identify the cognitive interaction of the university students. After the verification, it was found that the calculated T value (8.22) is greater than the T-table value (1.96) at the level of significance (0.05) and the degree of freedom (399). During test situations with ideas outside the test context or lack of experience in managing their own resources Table (7) illustrates this. 
Table (7) Arithmetic mean, standard deviation and $T$ value of cognitive interference scale.

\begin{tabular}{|l|l|l|l|l|l|l|}
\hline $\begin{array}{l}\text { The } \\
\text { sample }\end{array}$ & $\begin{array}{l}\text { The } \\
\text { middle } \\
\text { Arithmetic }\end{array}$ & $\begin{array}{l}\text { Deviatio } \\
\text { Normative } \\
\text { approach }\end{array}$ & $\begin{array}{l}\text { The } \\
\text { middle } \\
\text { Theoretical }\end{array}$ & $\begin{array}{l}\text { T value } \\
\text { Calculated }\end{array}$ & $\begin{array}{l}\text { T } \\
\text { value } \\
\text { Table }\end{array}$ & $\begin{array}{l}\text { Level of } \\
\text { significance }\end{array}$ \\
\hline 400 & 113.43 & 13.23 & 108 & 8.22 & 1.960 & Mark \\
\hline
\end{tabular}

Objective 4: In order to identify the differences in the degree of cognitive overlap among university students according to sex and specialization variables, the mean and standard deviations of the scores of the sample were obtained in the degree of cognitive overlap, as shown in Table (8).

Table (8): The arithmetic averages and the standard deviations of the scores of the sample in the degree of cognitive overlap according to gender variables and the academic specialization.

\begin{tabular}{|c|c|c|c|c|c|}
\hline $\begin{array}{l}\text { Study } \\
\text { specialization }\end{array}$ & \multicolumn{2}{|l|}{ Sex } & the sample & SMA & $\begin{array}{l}\text { standard } \\
\text { deviation }\end{array}$ \\
\hline \multirow[t]{2}{*}{ Scientific } & Male & 100 & \multirow{6}{*}{400} & 136.22 & 9.175 \\
\hline & Females & 100 & & 132.41 & 21.943 \\
\hline \multicolumn{2}{|l|}{ Total } & 200 & & 134.32 & 16.884 \\
\hline \multirow[t]{2}{*}{ Literary } & Male & 100 & & 111.49 & 12.897 \\
\hline & Females & 100 & & 109.88 & 17.881 \\
\hline \multicolumn{2}{|l|}{ Total } & 200 & & 110.68 & 15.571 \\
\hline
\end{tabular}

In order to determine the difference in the level of cognitive interaction according to sex variables and the study specialization, the analysis of the binary interaction was used. Table (9) shows this.

Table (9) Differences in the cognitive interaction according to sex variables and the academic specialization and interaction between them using the analysis of binary variance

\begin{tabular}{|l|l|l|l|l|l|}
\hline $\begin{array}{l}\text { Source of } \\
\text { Contrast }\end{array}$ & $\begin{array}{l}\text { Total } \\
\text { squares }\end{array}$ & $\begin{array}{l}\text { Degree } \\
\text { of } \\
\text { freedom }\end{array}$ & $\begin{array}{l}\text { Average } \\
\text { The } \\
\text { squares }\end{array}$ & $\begin{array}{l}\text { Alphanumeric } \\
\text { value } \\
\text { Calculated }\end{array}$ & $\begin{array}{l}\text { Level } \\
\text { Significance }\end{array}$ \\
\hline Sex & 734.410 & 1 & 734.410 & 2.793 & Not mark \\
\hline $\begin{array}{l}\text { Study } \\
\text { specialization }\end{array}$ & 55837 & 1 & 55837 & 212.358 & Mark \\
\hline $\begin{array}{l}\text { Sex } \times \text { Study } \\
\text { specialization }\end{array}$ & 121 & 1 & 121 & 0.460 & Not mark \\
\hline The error & 104122.900 & 396 & 262.937 & & \\
\hline Total & 160815.31 & 399 & & & \\
\hline
\end{tabular}


- A. The effect of sex (male and female): The results showed that there are no differences between males and females in the level of cognitive overlap because they are subject to the same sources of cognitive overlap and that the cognitive process is one and the same and is not related to individual differences of both sexes (male-female)

- B-The results showed that the difference between the average scores of human and scientific specialization is statistically significant for the scientific specialization. The researchers attribute this finding to the fact that the nature of the academic subjects in the scientific disciplines is more complex than the human specialties and requires high interpolation

The results and expectations of failure and success are high and sharp, or to the nature of questions in scientific materials that require advanced cognitive activities such as relations and problem solving, or may be attributed to the fact that the courses of scientific specialization more difficult and complex and accurate and difficult to deal with them constructively And requires strong motivation towards technical learning.

Objective 5: To determine the nature and direction of the relationship between the management of cognitive information and the cognitive interaction of university students, the computational and standard deviations of the total sample were calculated on the two variables and the correlation between them was calculated as in Table (10).

Table (10) Relationship between the management of cognitive information and cognitive overlap.

\begin{tabular}{|l|l|l|l|l|l|}
\hline $\begin{array}{l}\text { the } \\
\text { sample }\end{array}$ & $\begin{array}{l}\text { the } \\
\text { number }\end{array}$ & Variable & $\begin{array}{l}\text { Arithmetic } \\
\text { mean }\end{array}$ & $\begin{array}{l}\text { standard } \\
\text { deviation }\end{array}$ & $\begin{array}{l}\text { Coefficient } \\
\text { of } \\
\text { correlation }\end{array}$ \\
\hline \multirow{2}{*}{$\begin{array}{l}\text { the } \\
\text { college }\end{array}$} & \multirow{2}{*}{400} & $\begin{array}{l}\text { Knowledge } \\
\text { Management }\end{array}$ & 124.67 & 16.54 & \multirow{2}{*}{$0,44-$} \\
\cline { 3 - 5 } & $\begin{array}{l}\text { Cognitive } \\
\text { Interference }\end{array}$ & 133.43 & 13.23 & \\
\hline
\end{tabular}

\section{Conclusion} conclude:

In the light of the findings of the current research, the researchers

1. University students possess knowledge management in males and females and in scientific and human specialization.

2. University students suffer from cognitive overlap during their exams.

3-Knowledge overlap is more pronounced in the scientific disciplines and this affects their academic performance.

I would recommend paying attention to students to provide psychological and educational support to ensure the reduction of cognitive overlap, instructing teachers to increase students' awareness of their knowledge management, instructing students to use strategic and 
administrative processes for their knowledge and organize them effectively, rreparing teachers to take the modern educational techniques and interest in curriculum development and educating students about the methods of recollection and training them on strategies of refocusing. Other studies would also be required, such as the relationship between knowledge management and other variables.

\section{References:}

Abu, R., Hussein Mohamed (2006), Knowledge Learning, Jordan, Amman, Dar al-Masirah for publication and distribution.

Anastasi, A. (1976). Psychological Testing. New York: Mcmillan Publishing co., Inc

Allam, S. M. (2000). Educational and psychological measurement and evaluation. Its basics and its applications and contemporary trends, i 1, Dar alFikr al-Arabi, Cairo.

Al-Essawi, M. A. R. (1985). Measurement and Experimentation in Psychology and Education, University House, Beirut, Lebanon.

BJorklund, D. \& Harnishfeger, K. K. (1996). The Evolution of Inhibition Mechanisms and Their Role in Human Cognition Behavior, New York : Springer verla., 141-173.

Bandura, A. (2005). Self- efficacy: The exercise of control. New York: Freeman.

Broadbent, D. E., Cooper, P. F., Fitzgerald, P., Parkes, K. R. (1982).’The Cognitive Failure Questionnaire (CFQ) and its correlates". British Journal of Clinical Psychology, 21.

Sarason, I.G. (1988). "Anxiety, self-preoccupation, and attention", Anxiety Research, 1, 3-7.

Shammari, praise Abdul Wadood (2015): cognitive overlap and attention control and their relation to the anxiety of university students, the doctoral thesis Faculty of Education / Ibn Rushd for Human Sciences / University of Baghdad.

Northern, J.J. (2010). “Anxiety and Cognitive Performance: A Test of Predictions made by Cognitive Interference Theory and Attentional Control Theory". Unpublished doctoral dissertation. Bowling Green State University Matias, M. (2005). "Working memory, map learning, and spatial orientation: The effects of gender and encoding interference on the acquisition of survey knowledge", Dissertations \& Theses, University of Windsor (Canada).

Kahneman, D. (1973). Attention and Effort. Englewood Cliffs, NJ: PrenticeHall.

Kazdin, A. E. (1990). "Evaluation of the Automatic Thoughts Questionnaire: Negative cognitive processes and depression among children. Psycholgical Assessment", Journal of Consulting and Clinical Psychopedagogy, 2, 73-79 
Trapp, E. P, \&Kausler. P. H. (1958). “Test anxiety level and goalsetting behavior". Journal of Consulting Psychdogy, 22. 31 -34.

Rabee, M. S., (1994), Personal Measurement, Cairo, Dar Al Maarafa Publishing and Distribution. 